\title{
Insight into the species diversity of the quill mite genus Betasyringophiloidus Skoracki, 2011 (Prostigmata: Syringophilidae) on the basis of the DNA barcodes
}

\author{
Eliza Glowska ${ }^{1}$, Lukasz Broda $^{1}$, Miroslawa Dabert ${ }^{2}$ \\ ${ }^{1}$ Adam Mickiewicz University in Poznań, Faculty of Biology, Department of Animal Morphology, Poznań, Poland; \\ ${ }^{2}$ Adam Mickiewicz University in Poznań, Faculty of Biology, Molecular Biology Techniques Laboratory, Poznań, Poland
}

\begin{abstract}
Betasyringophiloidus Skoracki, 2011 is a genus of quill mites (Prostigmata: Syringophilidae) that is believed to contain mono-, steno- and polyxenous parasites associated with a wide range of passerine birds (Passeriformes) across the world. In this work we applied the DNA-barcode marker (mitochondrial cytochrome $c$ oxidase subunit I gene fragment, COI) to verify whether Betasyringophiloidus schoeniclus (Skoracki, 2002) and Betasyringophiloidus seiuri (Clark, 1964) are actual steno- and polyxenous species associated with the currently recognised host ranges, or their populations are highly host-specific, cryptic species. Our results revealed that a population living on the Tristram's bunting Emberiza tristrami Swinhoe (Emberizidae) in Russia, so far classified as $B$. schoeniclus, is a new cryptic species Betasyringophiloidus emberizae sp. nov. Both topologies of the neighbor-joining and maximum likelihood phylogenetic trees as well as genetic distance (11.9\% Kimura 2-parameter distance) (K2P) support species status of the mite population from E. tristrami. The same data support previously established conspecific status of $B$. seiuri found on the ovenbird Seiurus aurocapilla (Linnaeus) (Parulidae) (type host) and the northern waterthrush Parkesia noveboracensis (Gmelin) (Parulidae) and expand its range with a population found on a new host species Icterus pustulatus (Wagler) (Icteridae) with intraspecific K2P distance up to $1.9 \%$ and interpopulation distances ranging from 1.3 to $3.1 \%$.
\end{abstract}

Key words: cryptic species, bird parasites, molecular taxonomy, DNA-barcoding, COI

Betasyringophiloidus Skoracki, 2011 is a genus of mites (Prostigmata: Syringophilidae) which contains species living inside the quills of secondaries and coverts of several bird hosts in the Palaearctic, Nearctic and Afrotropical realms (Skoracki 2011, Glowska et al. 2015). Until now, the genus has been represented by five species recorded from six families of passerine birds (Passeriformes): Emberizidae, Motacillidae, Muscicapidae, Parulidae, Passeridae and Ploceidae (Skoracki 2011, Glowska et al. 2015, Skoracki et al. 2016).

Among already known species, three are monoxenous, Betasyringophiloidus motacillae (Bochkov et Mironov, 1998) recorded from Motacilla flava Linnaeus in Russia, Poland and Slovakia (Bochkov and Mironov 1998, Skoracki 2011, Klimovičová and Hromada 2014), Betasyringophiloidus phoenicurus Skoracki, 2011 parasitising Phoenicurus ochruros (Gmelin) in Poland (Skoracki 2011) and Betasyringophiloidus saxicolus Skoracki, 2011 found on Saxicola rubetra (Linnaeus) in Poland (Skoracki 2011).

Betasyringophiloidus schoeniclus (Skoracki, 2002) has been considered so far as a stenoxenous species parasitising buntings of the genus Emberiza Linnaeus, namely
Emberiza schoeniclus (Linnaeus) (type host) in Slovakia, Poland, Mongolia and Kazakhstan (Skoracki 2011), Emberiza rutila Pallas and Emberiza tristrami Swinhoe in Russia (Skoracki and Mironov 2013). The only putative polyxenous species within Betasyringophiloidus is Betasyringophiloidus seiuri (Clark, 1964) which has been previously recorded from 16 host species of the families Emberizidae, Parulidae, Passeridae and Ploceidae, predominantly in the USA, but also in Canada, Mexico, Togo and the Democratic Republic of the Congo (Skoracki et al. 2016, Skoracki 2017).

The vast majority of quill mites are believed to be monoand stenoxenous species (Skoracki 2011). However, identification of most previously described taxa has been carried out based entirely on the external morphology (e.g. Kethley 1970, Bochkov and Mironov 1999, Fain et al. 2000, Skoracki 2011). Delimitation of species boundaries within this group seems to be difficult sometimes and can be misleading because of uniform appearance and ambiguous differential morphological characters at low taxonomic levels.

For this reason, DNA-barcoding began to be used in quill mite taxonomy as a source of information supporting the 
Table 1. Mites and sequences used in this study.

\begin{tabular}{|c|c|c|c|c|}
\hline Mite species & Host species & Location & Specimen and DNA code & GenBank Access No. \\
\hline \multirow{7}{*}{$\begin{array}{l}\text { Betasyringophiloidus } \\
\text { emberizae sp. nov. }\end{array}$} & \multirow{7}{*}{$\begin{array}{l}\text { Emberiza tristrami } \\
\text { Swinhoe (Emberizidae) }\end{array}$} & \multirow{7}{*}{$\begin{array}{c}\text { RUSSIA } \\
\text { Novolitovsk, Partizansky District, } \\
\text { Primorsky Kray } \\
42^{\circ} 57^{\prime} 38.6^{\prime \prime N} ; 132^{\circ} 53^{\prime} 12.5^{\prime \prime} \mathrm{E}\end{array}$} & EG258 & MH457627 \\
\hline & & & EG259 & MH457625 \\
\hline & & & EG260 & MH457628 \\
\hline & & & EG683 & MH457630 \\
\hline & & & EG684 & MH457631 \\
\hline & & & EG685 & MH457629 \\
\hline & & & EG687 & MH457626 \\
\hline \multirow{4}{*}{$\begin{array}{l}\text { Betasyringophiloidus } \\
\text { schoeniclus (Skoracki, 2002) }\end{array}$} & \multirow{4}{*}{$\begin{array}{l}\text { Emberiza schoeniclus } \\
\text { (Linnaeus) (Emberizidae) }\end{array}$} & \multirow{4}{*}{$\begin{array}{c}\text { KAZAKHSTAN } \\
\text { South Kazakhstan Region, Kyzylkol } \\
\text { Lake, } 43^{\circ} 44^{\prime} 35^{\prime \prime N} ; 69^{\circ} 30^{\prime} 07^{\prime \prime} \mathrm{E}\end{array}$} & EG263 & MH457621 \\
\hline & & & EG264 & MH457622 \\
\hline & & & EG265 & MH457623 \\
\hline & & & EG266 & MH457624 \\
\hline \multirow{15}{*}{$\begin{array}{l}\text { Betasyringophiloidus seiuri } \\
\text { (Clark, 1964) }\end{array}$} & \multirow{5}{*}{$\begin{array}{l}\text { Seiurus aurocapilla } \\
\text { (Linnaeus) (Parulidae) }\end{array}$} & \multirow{5}{*}{$\begin{array}{c}\text { USA } \\
\text { Maryland, Allegany, Frostburg, } \\
39^{\circ} 33^{\prime} 39^{\prime \prime} \mathrm{N} ; 7^{\circ} 55^{\prime} 31^{\prime \prime} \mathrm{W}\end{array}$} & GE334 & MH457616 \\
\hline & & & GE335 & MH457617 \\
\hline & & & GE336 & MH457618 \\
\hline & & & GE337 & MH457619 \\
\hline & & & GE338 & MH457620 \\
\hline & \multirow{4}{*}{$\begin{array}{l}\text { Parkesia noveboracensis } \\
\text { (Gmelin) (Parulidae) }\end{array}$} & \multirow{4}{*}{$\begin{array}{c}\text { MEXICO } \\
\text { Veracruz, Los Tuxtlas } \\
18^{\circ} 35^{\prime} 7^{\prime \prime N} ; 95^{\circ} 4^{\prime} 31^{\prime \prime W}\end{array}$} & EG594 & MH457611 \\
\hline & & & EG663 & MH457608 \\
\hline & & & EG664 & MH457609 \\
\hline & & & EG665 & MH457610 \\
\hline & \multirow{6}{*}{$\begin{array}{l}\text { Icterus pustulatus } \\
\text { (Wagler) (Icteridae) }\end{array}$} & \multirow{6}{*}{\begin{tabular}{|c} 
MEXICO \\
Jalisco, Estación de Biología Chamela, \\
$19^{\circ} 29^{\prime} 55^{\prime \prime} \mathrm{N} ; 105^{\circ} 02^{\prime} 40.5^{\prime \prime} \mathrm{W}$
\end{tabular}} & EG307 & MH457606 \\
\hline & & & EG310 & MH457607 \\
\hline & & & EG673 & MH457612 \\
\hline & & & EG675 & MH457613 \\
\hline & & & EG676 & MH457614 \\
\hline & & & EG677 & MH457615 \\
\hline $\begin{array}{l}\text { Syringophiloidus } \\
\text { pseudonigritae Glowska, } \\
\text { Dragun-Damian et Dabert 2012 }\end{array}$ & $\begin{array}{l}\text { Pseudonigrita arnaudi } \\
\text { (Bonaparte) (Ploceidae) }\end{array}$ & TANZANIA & EG585 & MH457632 \\
\hline
\end{tabular}

morphological approach in taxon descriptions (e.g. Glowska et al. 2012a,b, 2016). Moreover, the efficiency of this tool in resolving systematic puzzles, such as female dimorphism detection and revealing the phenomenon of phenotypic plasticity has been shown (Glowska et al. 2013, 2014).

In this work, we applied the DNA-barcode marker (mitochondrial cytochrome $c$ oxidase subunit I gene fragment, COI) to verify whether morphology-based quill mite species, B. schoeniclus and B. seiuri, are steno- and polyxenous species having a very broad host range, or, in fact, they are highly host-specific cryptic species.

\section{MATERIALS AND METHODS}

\section{Animal material}

Mite material used in the study was collected in Russia (2008), Kazakhstan (2007), Mexico (2008), USA (2015) and Germany (2010) (Table 1). Drawings were made with an Olympus BH2 microscope with differential interference contrast (DIC) optics and a camera lucida. All measurements are in micrometres $(\mu \mathrm{m})$. The idiosomal setation follows Grandjean (1939) with modifications adapted for the Prostigmata by Kethley (1990). The system of nomenclature for leg chaetotaxy follows that proposed by Grandjean (1944). The application of these chaetotaxy schemes to Syringophilidae has recently been provided by Bochkov et al. (2008) with changes by Skoracki (2011). Latin and common names of the birds follow Clements et al. (2018).

Material depositories and abbreviations: AMU - Adam Mickiewicz University, Poznań, Poland; UMMZ BMOC - Museum of Zoology of the University of Michigan, Ann Arbor, USA B. OConnor reference number of collection; CNAC - Colección
Nacional de Ácaros, Instituto de Biología, Universidad Nacional Autónoma de México (UNAM), Mexico; USNM - Smithsonian Institution, National Museum of Natural History, Washington, D.C., USA; ZISP - Zoological Institute, Russian Academy of Science, St. Petersburg, Russia.

Voucher slides and corresponding DNA samples are deposited in the collection of the AMU under the identification numbers as indicated below. The sequences were deposited in GenBank under accession nos. as specified in Table 1.

\section{Molecular analysis}

Total genomic DNA was extracted from single specimens using DNeasy Blood \& Tissue Kit (Qiagen GmbH, Hilden, Germany) as described by Dabert et al. (2008). The COI gene fragment was amplified by PCR with degenerate primers: Aseq01F (GGAACRATATAYTTTATTTTTAGA) and Aseq03R (GGATCTCCWCCTCCWGATGGATT) (Glowska et al. 2014). PCR amplifications were carried out in $10 \mu \mathrm{l}$ reaction volumes containing $5 \mu 1$ of Type-it Microsatellite Kit (Qiagen), $0.5 \mu \mathrm{M}$ of each primer and $4 \mu \mathrm{l}$ of DNA template using a thermocycling profile of one cycle of $5 \mathrm{~min}$ at $95^{\circ} \mathrm{C}$ followed by 35 steps of $30 \mathrm{~s}$ at $95^{\circ} \mathrm{C}, 1 \mathrm{~min}$ at $50{ }^{\circ} \mathrm{C}$, $1 \mathrm{~min}$ at $72^{\circ} \mathrm{C}$, with a final step of $5 \mathrm{~min}$ at $72^{\circ} \mathrm{C}$.

After amplification PCR products were diluted two-fold with water and $5 \mu 1$ of the sample was analysed by electrophoresis on a $1 \%$ agarose gel. Samples containing visible bands were purified with thermosensitive Exonuclease I and FastAP Alkaline Phosphatase (Fermentas, Thermo Scientific, Göteborg, Sweden). The amplicons (585 bp) were sequenced in one direction using the Aseq01F primer. Sequencing was performed with BigDye Terminator v3.1 on an ABI Prism 3130XL Analyser (Applied Biosystems, Foster City, CA, USA). Sequence chromatograms were checked 
Table 2. Estimates of evolutionary divergences between COI sequences of Betasyringophiloidus ssp. from different hosts.

\begin{tabular}{|c|c|c|c|c|c|c|c|}
\hline \multirow{3}{*}{ Host species } & \multicolumn{7}{|c|}{$\mathrm{K} 2 \mathrm{P}$ distances $(\%)$} \\
\hline & \multirow{2}{*}{\multicolumn{2}{|c|}{ Within groups }} & \multicolumn{5}{|c|}{ Between groups } \\
\hline & & & 1. & 2. & 3. & 4. & 5. \\
\hline 1. Betasyringophiloidus emberizae sp. n. (E.t.)* & \multicolumn{2}{|c|}{0.0} & - & 11.9 & 9.9 & 9.5 & 9.8 \\
\hline 2. Betasyringophiloidus schoeniclus (E.s.)* & \multicolumn{2}{|c|}{0.0} & - & - & 11.5 & 10.4 & 11.4 \\
\hline 3. Betasyringophiloidus seiuri $(\text { S.a. })^{*}$ & \multicolumn{2}{|l|}{0.0} & - & - & - & 3.1 & 3.0 \\
\hline 4. Betasyringophiloidus seiuri (P.n.)* & \multicolumn{2}{|r|}{$1.9(\mathrm{SD} 0.4)$} & - & - & - & - & 1.3 \\
\hline 5. Betasyringophiloidus seiuri (I.p.)* & \multicolumn{2}{|l|}{$0.7(\mathrm{SD} 0.24)$} & - & - & - & - & - \\
\hline
\end{tabular}

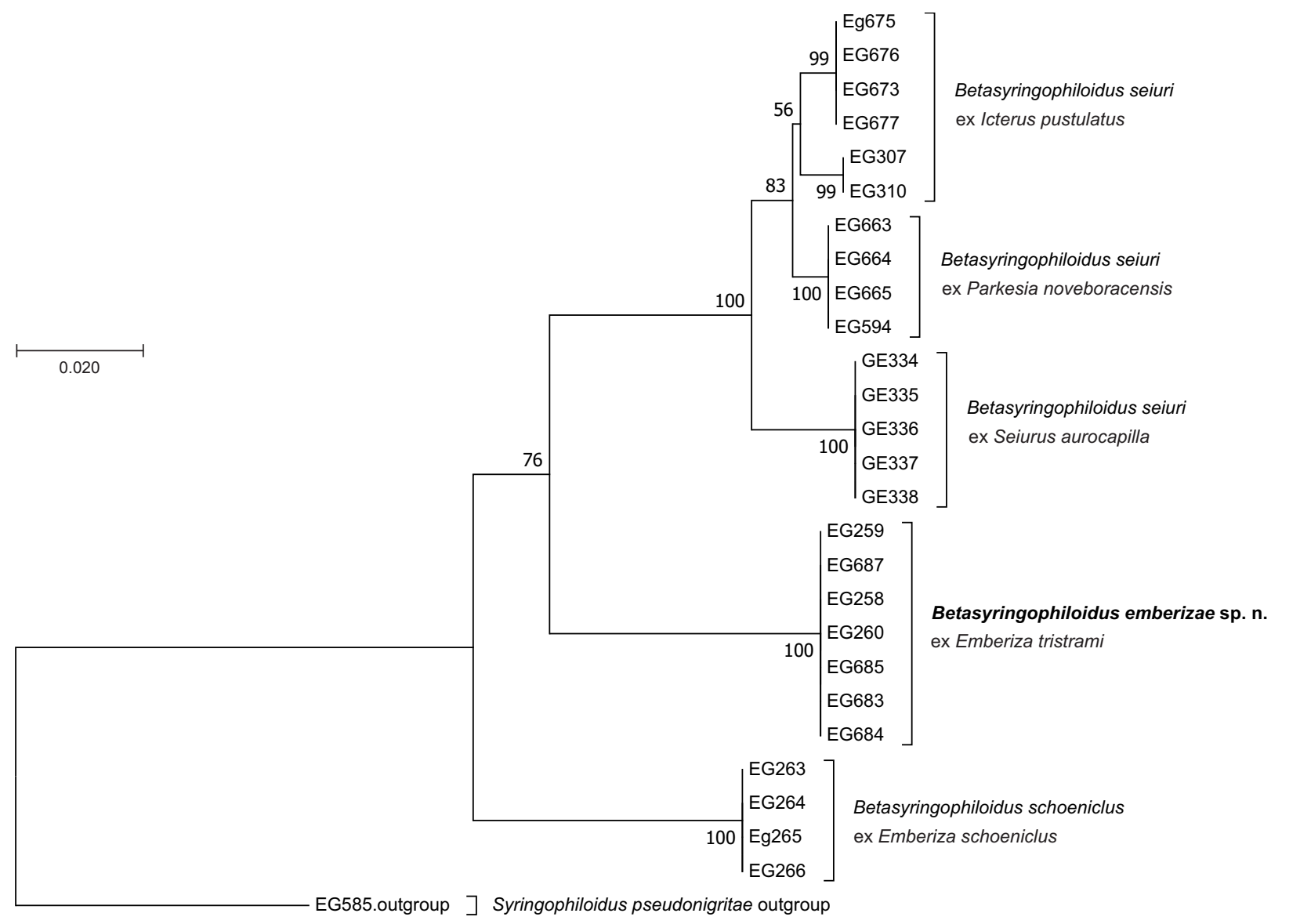

Fig. 1. Neighbor-joining phylogenetic tree of the species of Betasyringophiloidus Skoracki, 2011 based on the COI sequences. The tree was constructed in Mega v.7.

for accuracy and edited using Geneious R11 (Biomatters, Ltd., Auckland, New Zealand).

Phylogenetic associations between the studied taxa were estimated with neighbor-joining (NJ) and maximum likelihood (ML) methods implemented in MEGA7 (Kumar et al. 2016) and Garli v.2.0 software (Zwickl 2006), respectively. The codon-based model of nucleotide substitution (Goldman and Yang 1994) was used for ML analysis. Support for the recovered trees was evaluated with non-parametric 1,000 (NJ) and 100 (ML) bootstrap replicates (Felsenstein 1985). Pairwise distances between nucleotide COI sequences were calculated using Kimura's two-parameter (K2P) distance model (Kimura 1980) for all codon positions with MEGA 7.

Syringophiloidus pseudonigritae Glowska, Dragun-Damian et Dabert, 2012 was chosen as an outgroup to root the tree. Additionally, the sequence data were analysed using Automatic Barcode Gap Discovery (ABGD) method to delimit genetic clusters

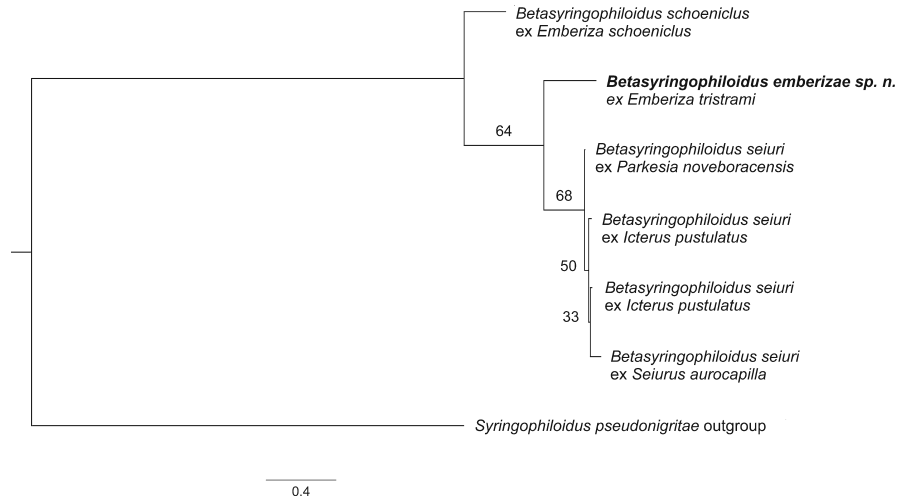

Fig. 2. Maximum likelihood phylogenetic tree of species of Betasyringophiloidus Skoracki, 2011 based on the COI sequences. The phylogenetic tree was constructed in Garli v.2.0. Both trees were rooted by Syringophiloidus pseudonigritae Glowska, Dragun-Damian et Dabert, 2012. 
A

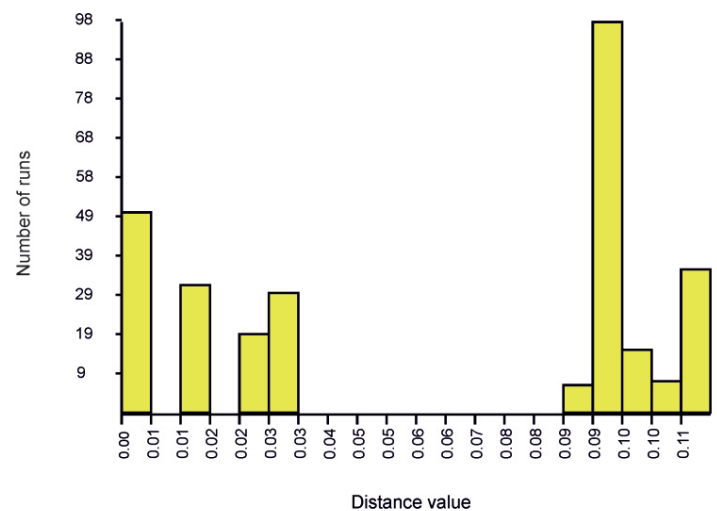

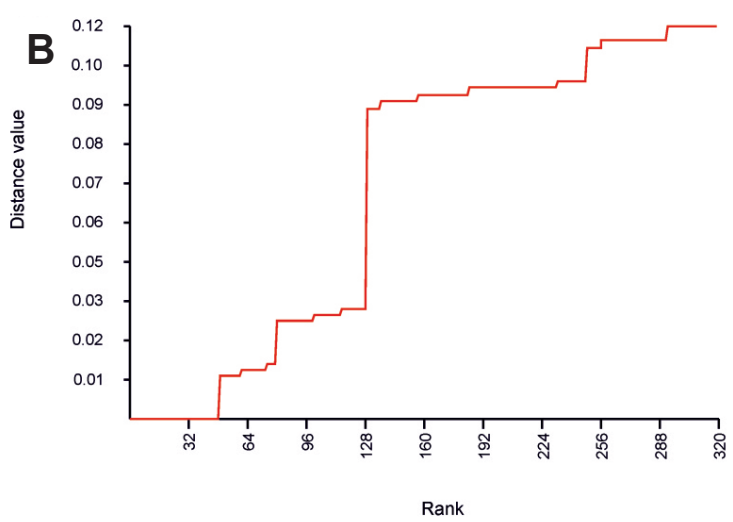

Fig. 3. Results of Automatic Barcode Gap Discovery (ABGD) analysis for COI sequences. A - Distribution of pairwise differences; B - Ranked pairwise differences.

by detecting a significant gap in the pairwise distance distribution (Puillandre et al. 2012). We used the online ABGD version (http://wwwabi.snv.jussieu.fr/public/abgd/abgdweb.html) with the default settings and the K2P distance model. Tree visualisations were prepared by tree editing tools in MEGA7 and Figtree v.1.4.2 (Rambaut 2014) (http://tree.bio.ed.ac.uk/).

\section{RESULTS}

\section{Family Syringophilidae Lavoipierre, 1953}

\section{Subfamily Syringophilinae Lavoipierre, 1953}

\section{Genus Betasyringophiloidus Skoracki, 2011}

\section{Molecular analysis}

Our COI alignment was 563 bp long and comprised 26 sequences of species of Betasyringophiloidus (ingroup) and one sequence of Syringophiloidus pseudonigritae (outgroup). There were no differences in the COI nucleotide sequences among mites collected on the same host species, except for Betasyringophiloidus seiuri found on Icterus pustulatus, which was represented by two COI haplotypes. The haplotypes found in $B$. seiuri differed in seven nucleotide positions $(0.67 \%, \mathrm{SD}=0.24, \mathrm{~K} 2 \mathrm{P})$ out of which, two were non-synonymous and leading to amino acid substitutions (glycine to serine and isoleucine to threonine).

The topologies of phylogenetic trees (Figs. 1, 2) revealed that populations from Emberiza schoeniclus and Emberiza tristrami are not a monophyletic but a paraphyletic taxon and showed that they are not the same, but separate, host-specific cryptic species. The same analysis supported the species integrity of the three populations of $B$. seiuri. The analysis (Fig. 1) revealed three maximally supported clades, each corresponding to the putative species: Betasyringophiloidus schoeniclus ex E. schoeniclus, a new species ex E. tristrami and a clade grouping B. seiuri ex Seiurus aurocapilla, Parkesia noveboracensis and I. pustulatus. The COI sequences of $B$. seiuri formed subclades according to the host species.

The ML analysis (Fig. 2) upheld the NJ result with a basic division into three species of Betasyringophiloidus; however, this result was weakly supported with bootstrap.
The intraspecific K2P distances among COI haplotypes (Table 2) within Betasyringophiloidus ssp. averaged from 0.0 to $1.9 \%(\mathrm{SD}=0.4)$ with no variation in the new species, B. schoeniclus and B. seiuri populations from $S$. aurocapilla and $P$. noveboracensis (each represented by one host-specific haplotype). Low K2P distance values were observed in B. seiuri from I. pustulatus $(0.7 \%, \mathrm{SD}=0.24)$, while relatively high intraspecific distance $(1.9 \%$, SD $=0.4$ ) occurred in $B$. seiuri populations derived from all three hosts.

The interspecific distances between the new species and $B$. seiuri and between the new species and B. schoeniclus were $9.5-9.9 \%$ and $11.9 \%$, respectively. Whereas the variation between different host populations of $B$. seiuri was at the intraspecific level, averaging $1.3-3.1 \%$, the distance between populations ex $P$. noveboracensis vs I. pustulatus was $1.3 \%$, ex $S$. aurocapilla vs I. pustulatus $3.0 \%$ and ex S. aurocapilla vs $P$. noveboracensis $3.1 \%$.

The ABGD method supported these results and detected a barcoding gap between 3 and $9 \%$ of pairwise distances (Fig. 3). Recursive partition analysis divided the dataset into six groups corresponding to all clades reconstructed by the NJ analysis, while initial partition of the sequence data with prior intraspecific divergence of $\mathrm{P}=2.15 \%$ divided data into three groups that corresponded to the analysed species.

\section{Taxonomy}

\section{Betasyringophiloidus emberizae sp. $\mathbf{n}$.}

Fig. 4A-E

ZooBank number for species:

urn:Isid:zoobank.org:act:08CCC32B-863D-4853-B567-8EDC9C2346C6

Description. Female (based on the holotype and three paratypes; range in parentheses). Total body length 700 (680-755).

Gnathosoma. Infracapitulum densely punctate. Each medial and lateral branch of peritremes with 4-5 and 8-10 chambers, respectively (Fig. 4D). Stylophore punctate, 180 (170-180) long.

Idiosoma. Propodonotal shield rounded anteriorly and densely punctate on entire surface. Length ratio of setae 
A

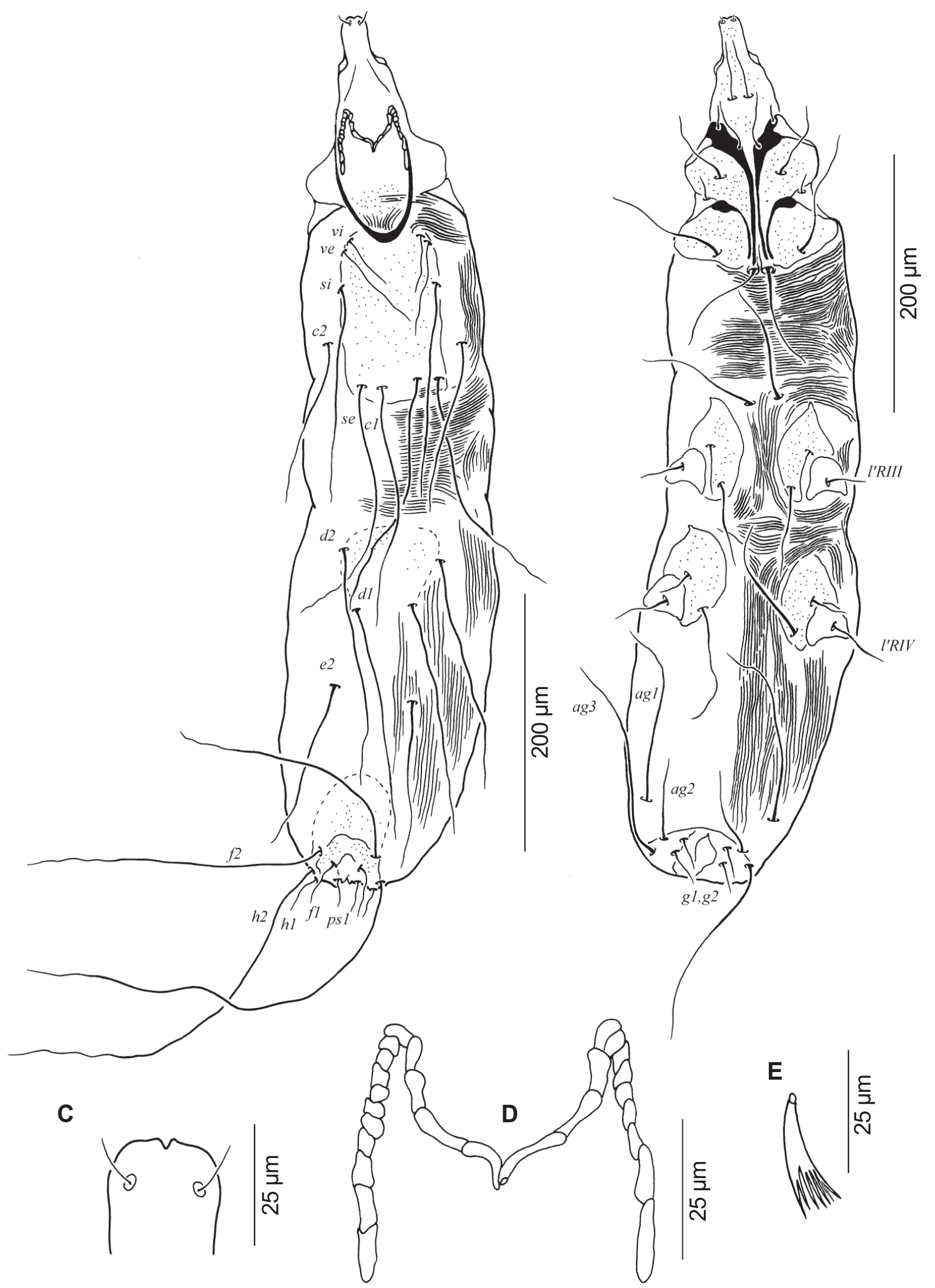

Fig. 4. Betasyringophiloidus emberizae sp. $n$. from the quill of the Emberiza tristrami (Swinhoe), female. A - dorsal view; $\mathbf{B}$ - ventral view; $\mathbf{C}$ - hypostomal apex; D - peritremes; $\mathbf{E}$ - fan-like setae p' of leg III. 
vi: ve: si 1 : 1.6-2.0 : 4.6. Hysteronotal shield weakly sclerotised and densely punctate, not fused to pygidial shield. Pygidial shield densely punctate, distinctly sclerotised in the area bearing bases of setae $f 1$ and $f 2$, its upper part weakly sclerotised. Setae $f 1$ and $h 1$ subequal in length. Length ratio of setae $a g 1:$ ag2 : ag3 1.1-1.5 : $1: 1.6-1.8$.

Legs. Coxal fields I-IV densely punctate. Setae $3 c 1.8$ 2.3 times longer than $3 b$. Fan-like setae $p$ ' and $p$ " of legs III-IV with 7 tines (Fig. 4E). Setae $t c$ " 1.3 times longer than $t c$ '.

Lengths of setae: vi 30 (30-40); ve 60 (55); si (135165); c2 (155-210); se 200 (180-225); c1 205 (180-205); d2 170 (165-185); d1 205 (185-245); e2 170 (155-195); f1 30 (30-40); f2 230 (235-270); h1 30 (30); h2 (270-295); ag1 155 (130-155); ag2 (105-120); ag3 (180-195); g1, g2 20 (20-25); ps1 20(20); tc' (55); tc” 70 (70); l'RIII (4555); l'RIV 30 (30-45); $3 b 35$ (30-35); 3c 80 (65-70); $4 b$ $30(30) ; 4 c 55$ (70-80).

Type material: Female holotype and four female paratypes from the quill of the Tristram's bunting E. tristrami (Passeriformes: Emberizidae), near Novolitovsk, Partizansky District, Primorsky Kray, 42 ${ }^{\circ} 57^{\prime} 38.6^{\prime \prime N}$; 132 ${ }^{\circ} 53^{\prime} 12.5^{\prime \prime E}$, Russia, 23 September 2008, coll. S. Mironov, SVM 08-0923-5; vouchers and DNA codes: EG261 (holotype), EG259, EG683685; DNA barcode GenBank accession numbers as specified in Table 1.

Material deposition: Female holotype (ZISP Sy-T-26) and one paratype in ZISP (ZISP AVB 16-0404-001); three female paratypes in AMU (AMU-SYR.1006.1-3).

Differential diagnosis: Betasyringophiloidus emberizae sp. $\mathrm{n}$. is most similar to B. schoeniclus with which shares almost all qualitative and quantitative characters. The subtle differences are noticeable only in the lengths of setae $v i$ (30-40 $\mu \mathrm{m}$ in B. emberizae and $40-55 \mu \mathrm{m}$ in B. schoeniclus) and $h 2(270-295 \mu \mathrm{m} v s$ 330-370 $\mu \mathrm{m})$. This relatively weak morphological differentiation between these two species does not reflect the high interspecific genetic variation between COI haplotypes of $B$. emberizae specimens and B. schoeniclus equaling $11.9 \%(\mathrm{~K} 2 \mathrm{P})$.

E ty m o log y: The name is taken from the generic name of the host and is a noun in the genitive case.

\section{Betasyringophiloidus schoeniclus (Skoracki 2002)}

Syringophiloidus schoeniclus - Skoracki 2002: 309, Figs. 9-16. Betasyringophiloidus schoeniclus - Skoracki 2011: 95, Figs. 66-67.

Ty p e host: Emberiza schoeniclus (Passeriformes: Emberizidae). Type locality: Slovakia.

Material examined: One female and two nymphs from quill of the reed bunting, E. schoeniclus (Passeriformes: Emberizidae); South Kazakhstan Region, Kyzylkol Lake, 434' $35^{\prime \prime} \mathrm{N}$; 69³0'07"E, 335 m, Kazakhstan, 10 October 2007, coll. A.V. Bochkov. Specimen vouchers and DNA codes: EG263 (female), EG264, EG697 (nymphs), EG698699 (exoskeletons lost); DNA barcode GenBank accession numbers are given in Table 1.

Host range: Emberizidae: Emberiza schoeniclus, Emberiza rutila - Skoracki (2011), Skoracki and Mironov (2013).

D i s t r i b u t i o n : Poland, Slovakia, Russia, Kazakhstan, Mongolia.
Material deposited: One female and two nymphs in AMU (AMU-SYR.1007.1-3).

Remarks. In Skoracki and Mironov (2013), B. schoeniclus was also reported from E. tristrami from Russia, but our molecular analysis has revealed that population from E. tristrami belongs to a distinct new species, $B$. emberizae, described above.

\section{Betasyringophiloidus seiuri (Clark, 1964)}

Syringophilus seiuri - Clark 1964: 82, Figs. 7, 20, $24,25$.

Syringophiloidus seiurus - Kethley 1970: 50.

Syringophiloidus seiuri - Bochkov and Galloway 2001: 2025, Fig. 9.

Syringophiloidus zonotrichia - Bochkov et al. 2011: 203, Fig. 1.

Betasyringophiloidus seiuri - Skoracki et al. 2016: 458.

Type host: Seiurus aurocapilla (Linnaeus) (Passeriformes: Parulidae).

Type locality: USA (Maryland).

Host range: A polyxenous species inhabiting 17 host species belonging to the four families: Parulidae $-S$. aurocapilla (type host), Geothlypis philadelphia (Wilson), Helmitheros vermivorum (Gmelin), Oreothlypis peregrina (Wilson), Oreothlypis ruficapilla (Wilson), Setophaga palmarum (Gmelin), Setophaga pensylvanica (Linnaeus), Parkesia noveboracensis (Gmelin); Passerellidae-Melospiza georgiana (Latham), Melospiza lincolnii (Audubon), Melospiza melodia (Wilson), Zonotrichia albicollis (Gmelin); Ploceidae - Quelea erythrops (Hartlaub), Pachyphantes superciliosus (Shelley), Ploceus baglafecht (Daudin), Ploceus xanthops (Hartlaub) (Skoracki et al. 2016, Skoracki 2017); and Icteridae - I. pustulatus (new host).

Distribution: Canada, USA, Mexico, Togo, Democratic Republic of the Congo, Kenya.

Material examined: Five females from the quill of the type host the ovenbird $S$. aurocapilla (Passeriformes: Parulidae), (USNM 643672), Allegany, Frostburg, Dans Mountain Wildlife Management Area, Warnick Road Entrance, Maryland, USA, 17 June 2010, bird specimen coll. C.A. Gebhard; mites sampled by E. Glowska; specimen vouchers and DNA codes: GE334-335, GE337-338 (exoskeletons saved), GE336 (exoskeleton lost); DNA barcode GenBank accession nos. are given in Table 1; three females from the northern waterthrush P. noveboracensis (Passeriformes: Parulidae), Los Tuxtlas, Veracruz, $18^{\circ} 35^{\prime} 7^{\prime \prime} \mathrm{N}$; 954'31"W, Mexico, 30 April 2008, coll. S. Mironov, SVM 08-0430-7/3; specimen vouchers and DNA codes: EG594, EG663-664, EG665 (exoskeleton lost); DNA barcode GenBank accession nos. are given in Table 1; six females from the streak-backed oriole I. pustulatus (Passeriformes: Icteridae), Jalisco, Estación de Biología Chamela, $19^{\circ} 29^{\prime} 55^{\prime \prime} \mathrm{N} ; 105^{\circ} 02^{\prime} 40.5^{\prime \prime} \mathrm{W}, 19$ May 2008, coll. S. Mironov, SVM 08-0519-3/2, specimen vouchers and DNA codes: EG310, EG677 (exoskeletons saved), EG307, EG673, EG675-676 (exoskeletons lost); DNA barcode GenBank accession nos. are given in Table 1 .

Mate rial de po s i ted: Seiurus aurocapilla: two females deposited in AMU (AMU-SYR.1008.1-2) and three females in the USNM; Parkesia noveboracensis: one female in the UMMZ BMOC, one female in the CNAC and one female in the AMU (AMU-SYR.1009.1); Icterus pustulatus: one female in the UMMZ BMOC, one female in the CNAC, two females in the ZISP (ZISP AVB 16-0404-002) and two females in the AMU. 


\section{DISCUSSION}

Both topologies of the phylogenetic trees (Figs. 1, 2) and K2P distances (Table 2) support the existence of three clearly defined species: Betasyringophiloidus emberizae sp. n. ex Emberiza tristrami and two previously known species, i.e. Betasyringophiloidus schoeniclus ex Emberiza schoeniclus (type host) and Betasyringophiloidus seiuri from Seiurus aurocapilla (type host), Parkesia noveboracensis and Icterus pustulatus (new host). Due to morphological similarity of $B$. emberizae and B. schoeniclus, individuals collected from different bird species have so far been treated as the same species B. schoeniclus (see Skoracki and Mironov 2013). Even though morphological differences between populations from $E$. tristrami and $E$. schoeniclus are not obvious and, except for the length of setae $h 2$, their measurements overlap, molecular data indicate that these populations are separate species. Genetic distances between specimens of $B$. emberizae and $B$. schoeniclus $(11.9 \%)$ are comparable to the interspecific level observed between B. emberizae and B. seiuri (9.5-9.9\%) and between $B$. schoeniclus and B. seiuri (10.4-11.5\%), as well as among the species in other previously barcoded syringophilid genera (9.6-14.7\%) (Glowska, unpublished data). The intraspecific distances are much lower (0.0-1.9\%) and similar to the interpopulation values, i.e. $1.3-3.1 \%$ between populations of $B$. seiuri from $S$. aurocapilla, $P$. noveboracensis and I. pustulatus that are comparable to those observed within other stenoxenous quill mites $(0.0$ 2.0\%) (Glowska et al. 2013).

Despite relatively high intraspecific level of genetic variability within $B$. seiuri sensu lato $(1.9 \%)$, the host-specific populations are very homogeneous and clearly distinct from each other (1.3-3.1\%). Especially, the population found on $S$. aurocapilla with a $3.0-3.1 \%$ distance value seems to be highly distant from the other two populations. Assuming restricted gene flow between individuals from S. aurocapilla, P. noveboracensis and I. pustulatus, it is conceivable to assume that these lineages will evolve into distinct species and we are dealing here with species of Betasyringophiloidus in statu nascendi.

It may be further supported by the fact that their host contact seems to be limited. Although the geographical coverage of the three $B$. seiuri host species overlaps, their interactions do not seem to be frequent due to the habitat preferences (BirdLife Interanational 2019). Considering also the isolated lifestyle of quill mites, the chance of gene flow between populations seems to be minimal. However, we do not have enough evidence at present to state if gene flow occurs or not. Also, the distance values do not seem to reach the threshold considered as an indicator of species separation.

Our data show that the same quill mite species may inhabit phylogenetically distant hosts (as B. seiuri found on parulid and icterid birds) and that hosts belonging to the same genus may harbour distinct mite species of the same genus (E. tristrami and E. schoeniclus infected with $B$. emberizae and B. schoeniclus, respectively). It calls into question the currently prevailing idea that quill mites are mainly mono- and stenoxenous parasites. Our data suggest that their distribution is more random and horizontal transfers are more common than has been previously assumed.

Recently, a new syringophilid species, Aulonastus similis Broda, Dabert et Glowska, 2016, has been discovered from hosts belonging to different passerine suborders (Passeri and Tyranni) (Broda et al. 2016), suggesting that distribution of these mites is a result of host switching rather than cophylogenetic processes. In contrast, the classic view of parasite-host associations is supported by another recently described species, Syringophiloidus plocei Glowska, Broda, Gebhard et Dabert, 2016, confirmed molecularly from three species of Ploceus Cuvier in Gabon, Ploceus cucullatus (Muller), Ploceus aurantius (Vieillot) and Ploceus nigerrimus (Vieillot) (Glowska et al. 2016).

There is evidence that quill mite diversity and host specificity are much more complicated than we have expected and there are still many mysteries in terms of evolutionary associations in the host-parasite system. It seems possible that molecular data such as DNA-barcodes, when supplementing classical morphological studies, will play a crucial role in determining accurate species boundaries in this group of mites.

Acknowledgements. We are very grateful to the late Andre V. Bochkov (Russian Academy of Sciences, St. Petersburg, Russia), Pavel Klimov (Museum of Zoology of the University of Michigan, Ann Arbor, USA) and Sergey V. Mironov (Russian Academy of Sciences, Moscow, Russia), who collected the material and made it available for our research. The collection of mites in Mexico was made under the license No FAUT-0209 issued by the Dirección General de Vida Silvestre (Mexico); the field expedition was supported by the grant from the U.S. National Science Foundation (DEB-0613769) to Barry M. OConnor (Museum of Zoology, University of Michigan, Ann Arbor, USA). We also thank the staff of the Department of Vertebrate Zoology, Division of Birds, Smithsonian Institution, National Museum of Natural History, Washington, D.C., USA (USNM) for making the collection of feathers available for this study.

\section{REFERENCES}

BirdLifE InTERnATIONAL 2019: IUCN Red List for birds. http:// www.birdlife.org

Bochkov A.V., Mironov S.V. 1998: Quill mites of the family Syringophilidae Lavoipierre, 1953 (Acariformes: Prostigmata) parasitic on birds (Aves) of the fauna of the former USSR. Acarina 6: $3-16$.
Bochkov A.V., Mironov S.V. 1999: New quill mite species of the family Syringophilidae (Acari: Cheyletoidea) from the European part of Russia. Acarina 7: 35-45.

Bochkov A.V., OConnor B.M., Wauthy G. 2008: Phylogenetic position of the family Myobiidae within the Prostigmata (Acari: Acariformes). Zool. Anz. 247: 15-45. 
Broda L., Dabert M., Glowska E. 2016: Aulonastus similis n. sp. - combined description (morphology with DNA barcode data) of a new quill mite species (Syringophilidae) parasitising passeriform birds (Tyrannidae, Cardinalidae) in Mexico. Syst. Parasitol. 93: 715-719.

Clements J.F., Schulenberg T. S., Iliff M.J., Roberson D., Fredericks T.A., Sullivan B.L., Wood C.L. 2017: The eBird/Clements checklist of birds of the world: v2018. Downloaded from http:/www.birds.cornell.edu/clementschecklist/ download/

Dabert J., Ehrnsberger R., Dabert M. 2008: Glaucalges tytonis sp. n. (Analgoidea, Xolalgidae) from the barn owl Tyto alba (Strigiformes, Tytonidae): compiling morphology with DNA barcode data for taxon descriptions in mites (Acari). Zootaxa 1719: 41-52.

Fain A., Bochkov A.V., Mironov S.V. 2000: New genera and species of quill mites of the family Syringophilidae (Acari: Prostigmata). Bull. Inst. Roy. Sci. Nat. Belg. 70: 33-70.

Felsenstein J. 1985: Confidence limits on phylogenies: an approach using the bootstrap. Evolution 39: 783-791.

Glowska E., Broda L., Dabert M. 2016: A new quill mite Syringophiloidus plocei sp. nov. (Prostigmata: Syringophilidae) parasitizing ploceid birds (Passeriformes) in Gabon - a combined description using morphology and DNA barcode data. Acta Parasitol. 61: 562-566.

Glowska E., Chrzanowski M., Kaszewska K. 2015. Checklist of the quill mites (Acariformes: Syringophilidae) of the World. Zootaxa 3968: 1-81.

Glowska E., Dragun-Damian A., Broda L., Dabert J., DaBERT M. 2014: DNA barcodes reveal female dimorphism in syringophilid mites (Actinotrichida: Prostigmata: Cheyletoidea) Stibarokris phoeniconaias and Ciconichenophilus phoeniconaias are conspecific. Folia Parasitol. 61: 272-276.

Glowska E., Dragun-Damian A., Dabert J. 2012a: A new quill mite Syringophiloidus pseudonigritae sp. nov. (Prostigmata, Syringophilidae) parasitizing Pseudonigrita arnaudi (Passeriformes, Ploceidae) - a combined description using morphology and DNA barcode data. Zootaxa 3532: 64-68.

Glowska E., Dragun-Damian A., Dabert J. 2012b: Picobia dziabaszewskii sp. nov. (Acari, Syringophilidae) - combined description (morphology with DNA barcode data) of a new quill mite species parasitizing Garrulax formosus (Passeriformes: Leiothrichidae). Zootaxa 3224: 57-61.

Glowska E., Dragun-Damian A., Dabert J. 2013. DNA-barcoding contradicts morphology in quill mite species Torotrogla merulae and T. rubeculi (Prostigmata: Syringophilidae). Folia Parasitol. 60: 51-60
Goldman N., YANG Z. 1994: A codon-based model of nucleotide substitution for protein-coding DNA sequences. Mol. Biol. Evol. 11: $725-736$.

GRANDJEAN F. 1939: Les segments postlarvaires de l'hysterosoma chez les oribates (acariens). Bull. Soc. Zool. France 64: 273-284.

Grandjean F. 1944: Observations sur les acariens de la famille Stigmaeidae. Arch. Sci. Phys. Nat. 26: 103-131.

Kethley J.B. 1970: A revision of the family Syringophilidae (Prostigmata: Acarina). Contrib. Am. Entomol. Inst. 6: 1-76.

Kethley J.B. 1990: Acarina: Prostigmata (Actinedida). In: D.L. Dindal (Ed.), Soil Biology Guide. Wiley and Sons, New York, pp. 667-754.

Kimura M. 1980: A simple method for estimating evolutionary rate of base substitutions through comparative studies of nucleotide sequences. J. Mol. Evol. 16: 111-120.

Klimovičová M., Hromada M. 2014: New hosts and localities of quill mites (Acari: Syringophilidae) parasitising birds in Slovakia. Acta Univ. Prešoviensis, Folia Oecol. 11: 37-42.

Kumar S., Stecher G., Tamura K. 2016: MEGA7: Molecular evolutionary genetics analysis version 7.0 for bigger datasets. Mol. Biol. Evol. 33: 1870-1874.

Puillandre N., Lambert A., Brouillet S., Achaz, G. 2012: ABGD, Automatic Barcode Gap Discovery for primary species delimitation. Mol. Ecol. 21: 1864-1877.

Rambaut A. 2014: Tree Figure Drawing Tool Version 1.4.2. Institute of Evolutionary Biology, University of Edinburgh. Available via http://tree.bio.ed.ac.uk/

SKORACKI M. 2002: Three new species of the ectoparasitic mites of the genus Syringophiloidus Kethley, 1970 (Acari: Syringophilidae) from passeriform birds from Slovakia. Folia Parasitol. 49: 305-313.

SkoraCKi M. 2011: Quill mites (Acari: Syringophilidae) of the Palaearctic region. Zootaxa 2840: 1-414.

SkoraCki M. 2017: Quill mites (Acariformes: Syringophilidae) associated with birds of Mexico. Zootaxa 4282: 179-191.

SkoraCKi M., Mironov, S.V. 2013: New species and records of quill mites of the family Syringophilidae (Acari: Prostigmata) from the passerines (Aves: Passeriformes) from the Russian Far East. Zootaxa 3641: 554-564.

Skoracki M., Spicer G.S., OConnor B.M. 2016: A systematic review of the subfamily Syringophilinae (Acari: Syringophilidae) of the Nearctic region. Part 1: quill mites associated with passerines (Aves: Passeriformes). Zootaxa 4084: 451-494.

ZWICKL D.J. 2006: Genetic algorithm approaches for the phylogenetic analysis of large biological sequence datasets under the maximum likelihood criterion. The University of Arizona, Tucson. 